\title{
QUALITY IMPROVEMENT OF EXPORTABLE FISH AND PRAWN THROUGH POST-HARVEST LOSS REDUCTION IN KULIERCHAR UNDER PARTICIPATORY STAKEHOLDER-BASED APPROACH
}

\author{
A. A. K. M. Nowsad, M. N. Hassan, M. M. Hossain, M. S. Hoque, \\ M. A. Siddique and M. R. Islam \\ Department of Fisheries Technology, Bangladesh Agricultural University \\ Mymensingh-2202, Bangladesh
}

\begin{abstract}
A participatory stakeholder-based approach was employed to improve the quality of exportable fish and prawn landed in Kulierchar of Kishoregonj through reduction of the post harvest loss and its impacts were assessed. Primary data revealed that wet fish were minimally washed with clean water immediately after harvest. Ice boxes were not used in any stages from harvest to processing plants. Bamboo split baskets were mostly used to keep or carry fish. Landed fish were found to be dispersed on plastic mat or polythene paper kept on earthen floor of the wholesaler shed, called "Arat". Icing of individual catch soon after harvest was very insignificant, ranging from 2 - $15 \%$ only. Prawn were found to be iced during transport to landing center at little higher rate (32\%), but most of the other fish were not significantly iced during transport to landing center. Primary awareness of the beneficiaries on quality deterioration of fish was assessed and the impacts of participatory awareness development tools (PRA and RRA, personal contacts, brain storming and awareness development training) on export, income, nutrition and improved handling of landed exportable prawn/fish were re-assessed. Efficacy of such measures to improve the situation were monitored for sixteen months. Awareness in terms of benefit of good practices was high in factory technicians. Other stakeholders had very shallow or poor knowledge on use of improved handling and processing of fish. Participatory tools employed in this study was found to be effective in developing awareness of stakeholders in different value chains of wet fish handling and distribution and reducing post-harvest loss.
\end{abstract}

Key Words: Post-harvest loss reduction in fish, Quality improvement, Bamboo basket, Ice box, Landing centre

\section{INTRODUCTION}

Kulierchar of Kishoregonj District is one of the major freshwater fish landing centers of the country. Most of the fishes of Haor fisheries of Kishoregonj, Sunamgonj, Sylhet and Mouluvibazar districts are landed in Kulierchar. A significant portion of the landed fish is 
exported to Europe and Middle-east. But the fishes are not adequately taken care off during harvest and post-harvest handling, preservation and processing. The exporters have often been reported to suffer from great economic loss in the form of rejection of part or full of the consignment.

The small freshwater fish are most susceptible to spoilage due to their comparative small size and vulnerability of constituent proteins and lipids (Nowsad, 2004). Since the quality loss of fish is not understood at least up to $50 \%$ of deterioration by common organoleptic means (Sakaguchi, 1990), consumers generally take it without any complain on quality. This brings about serious catastrophe in the nutrition status of the half-starved and nutrition-deprived people as well as the health conscious one (Nowsad, 2005a, 2005b). On the other hand, as there is no adequate preservation or storage facilities, exporters suffer from great economic loss year after year due to low price offered by both local and foreign buyers for quality deterioration. If such serious quality loss of exportable fish in Kulierchar is not encountered by appropriate means, the livelihood of the poor local fishers and traders will be in stake, common people will be more nutrition-deprived and nation will be deprived from foreign currency. These quantitative and qualitative losses, however, can be minimized in great extent by the awareness development of various stakeholders for adequate handling, preservation and processing practices in fish. Considering such backdrop the efficacy of a participatory stakeholder-based approach to improve the quality of exportable fish and prawn landed in Kulierchar of Kishoregonj and the reduction of the post harvest quality loss were assessed in this study.

\section{MATERIALS AND METHODS}

\section{Selection of study area and beneficiaries}

Kulierchar main fish landing center along with adjacent landing sites, local fish markets and a fish processing plant were taken under investigation. The fishermen, fisher-women and fish traders directly involved in harvest and distribution of exportable fish were selected as the primary target beneficiaries. The middlemen, aratdars, wholesalers and processors/operators of processing plant involved in supply, distribution and processing of exportable fish were selected as the secondary beneficiaries.

\section{Baseline survey}

A participatory baseline survey was conducted to collect information on existing postharvest handling situation of exportable prawn/fish, constraints of harvest, handling, icing and their solution options.

\section{Awareness creation and development}

Awareness of the beneficiaries' was created through PRAs, awareness raising campaigns, personal contacts and distribution of awareness materials. 


\section{Training and capacity building}

The beneficiaries in different groups were trained to build up their capacity and technical skills. First, the project technical and field staffs and then the project beneficiaries were trained on improved handling and processing of fish highlighting the reduction of postharvest loss in this sector.

\section{Transfer of technology}

Existing methods for handling and preservation of fish were improved at field level with participation of the stakeholders. For this purpose, several method and result demonstration training were conducted. Successful practices and techniques were disseminated to the users of other regions through awareness materials, government and non government extension service like Upazila Fisheries Officer, NGOs, etc.

\section{Quality tests}

Quality of the fish in different stages from harvest to processing was analyzed through subjective tests. Fish and frozen fish products were judged by the organoleptic methods. The sensory attributes with numerical scores employed in sensory analyses for the quality assessment of fish have been given in Table 1 (modified based on Howgate et al., 1992). General grading of fish obtained through the analysis of defect points (DP) are given in Table 2 (Howgate et al., 1992).

Table 1. Attributes and defect points for quality assessment of wet fish

\begin{tabular}{|c|c|c|c|}
\hline Attributes & Defect & $\begin{array}{l}\text { Defect } \\
\text { points }\end{array}$ & Grade \\
\hline \multirow{2}{*}{$\begin{array}{l}\text { 1. Odour of neck when } \\
\text { broken }\end{array}$} & a) Natural odour & 1 & Acceptable \\
\hline & b) Faint or sour odour & 5 & Reject \\
\hline \multirow[t]{4}{*}{ 2. Odour of gills } & a) Natural odour & 1 & Excellent \\
\hline & b) Faint sour odour & 2 & Good \\
\hline & c) Slight moderate sour odour & 3 & Acceptable \\
\hline & d) Moderate to strong sour odour & 5 & Reject \\
\hline \multirow[t]{4}{*}{ 3. Colour of gills } & a) Slight pinkish red & 1 & Excellent \\
\hline & b) Pinkish red to brownish & 2 & Good \\
\hline & c) Brown or grey & 3 & Acceptable \\
\hline & d) Bleached colour, thick yellow slime & 5 & Reject \\
\hline \multirow[t]{4}{*}{ 4. General appearance } & a) Full bloom, bright, shining, iridescent & 1 & Excellent \\
\hline & b) Slight dullness and loss of bloom & 2 & Good \\
\hline & c) Definite dullness and loss of bloom & 3 & Acceptable \\
\hline & d) Reddish lateral line, dull, no bloom & 5 & Reject \\
\hline \multirow[t]{3}{*}{ 5. Slime } & a) Usually clear, transparent and uniformly spread & 1 & Excellent \\
\hline & b) Becoming turbid, opaque and milky & 2 & Good \\
\hline & c) Thick sticky, yellowish or green colour & 5 & Reject \\
\hline \multirow[t]{4}{*}{ 6. Eye } & a) Bulging with protruding lens, transparent eye cap & 1 & Excellent \\
\hline & b) Slight cloudy of lens and sunken & 2 & Good \\
\hline & c) Dull, sunken, cloudy & 3 & Acceptable \\
\hline & d) Sunken eyes covered with yellow slime & 5 & Reject \\
\hline \multirow[t]{4}{*}{ 7. Consistency of flesh } & a) Firm and elastic & 1 & Excellent \\
\hline & b) Moderately soft and some loss of elasticity & 2 & Good \\
\hline & c) Some softening & 3 & Acceptable \\
\hline & d) Limp and flabby & 5 & Reject \\
\hline
\end{tabular}


Table 2. Grading of fish on the basis of the defect points

\begin{tabular}{c|c|l}
\hline Grade & Average DP & \multicolumn{1}{c}{ Comments } \\
\hline a & $<2$ & Excellent/highly acceptable \\
b & 2 to $<3$ & Good/acceptable \\
c & 3 to $<4$ & Poor/can be accepted with care \\
d & 4 to 5 & Bad/should be rejected \\
\hline
\end{tabular}

Proximate composition of the products was done by the standard Methods of AOAC (1990). Total volatile base nitrogen and peroxide values were determined by the methods of Miwa and Ji (1992). Simple statistics were performed to compare the data according to Shil and Debonath (1992).

\section{RESULTS AND DISCUSSION}

\section{Fish landing and processing in Kulierchar}

Commercial freshwater species are exported through fish processing plants of Kulierchar and packers and exporters through Dhaka-based frozen/chilled product export group to Europe, USA and Middle-east. Major processed products along with local and scientific names of raw materials are presented in Table 3.

\section{Handling of wet fish}

Fishes were hardly washed with clean water immediately after harvest. In case of small fish like Puntias sp. only $10 \%$ and in bigger fin fishes a $20-40 \%$ of the hauls were cleaned by thorough washing. A $65 \%$ fisherman washed their catch of giant prawn, which was still insignificant.

Washing and cleaning efforts of fish and prawn were very low during transport to landing and also immediately after landing (Table 4). However, almost all of the fishes were washed and cleaned in aratders before icing.

Fishermen mostly used small narrow-mouth fine meshed basket made of split bamboo (Table 5), sometimes they used aluminum or steel containers during harvest. After accumulation of the catches the fishes or prawn were transported to the landing center by large mouth split-bamboo basket or bamboo basket inner-wrapped with polythene sheet.

Icing practiced as soon as harvest was very poor ranging from $2-15 \%$ only (Table 6). Prawn were found to be iced during transport to landing center at little higher rate (32\%), but most of the other fish were not significantly iced during transport to landing center. Rate of icing was reduced immediately after landing even in case of prawn and some other valued species. But after wholesale in Arat, almost all of the prawns and fin-fishes were iced, because of their transportation to distant places. 
Table 3. Major fish species exported from Kulierchar region

\begin{tabular}{|c|c|c|c|}
\hline No. & Local name & Scientific name & Product type \\
\hline 1. & Golda, Icha, Chaumma & Macrobrachium rosenbergii & Frozen block, IQF, cooked \\
\hline 2. & Icha, Chaumma & Macrobrachium malcomsoni & Frozen block, IQF, cooked \\
\hline 3. & Aair/Guchi & Mystus aor & Frozen semi-IQF \\
\hline 4. & Gulsha & Mystus vittatus & Frozen block \\
\hline 5. & Tengra & Mystus tengara & Frozen block \\
\hline 6. & Pabda & Ompok pabda & Frozen block \\
\hline 7. & Raj Pabda & Ompok bimaculatus & Frozen block \\
\hline 8. & Silong & Silonia silondia & Frozen block \\
\hline 9. & Bacha & Eutropiichthys vacha & Frozen block \\
\hline 10. & Boal & Wallago attu & Frozen semi-IQF \\
\hline 11. & Rui & Labeo rohita & Frozen semi-IQF \\
\hline 12. & Catla & Catla catla & Frozen semi-IQF \\
\hline 13. & Mrigal & Cirrhina mrigala & Frozen semi-IQF \\
\hline 14. & Calibaush & Labeo calbasu & Frozen semi-IQF \\
\hline 15. & Garua & Clupisoma garua & Frozen block \\
\hline 16. & Batashi & Clupisoma atherinoides & Frozen block \\
\hline 17. & Rita & Rita rita & Frozen block, semi-IQF \\
\hline 18. & Elong & Rasbora elonga & Frozen block \\
\hline 19. & Mola & Amblypharyngodon mola & Frozen block \\
\hline 20. & Sarpunti & Puntias sarana & Frozen semi-IQF \\
\hline 21. & Chital & Notopterus chitala & Frozen semi-IQF \\
\hline 22. & Foli & Notopterus notopterus & Frozen block \\
\hline 23. & Kajali & Alia coila & Frozen block \\
\hline 24. & Bele & Glossogobius giuris & Frozen semi-IQF \\
\hline 25. & Shing & Heteropneustes fossilis & Frozen block \\
\hline 26. & Magur & Clarias batrachus & Frozen block, semi -IQF \\
\hline 27. & Koi & Anabas testedineus & Frozen block \\
\hline 28. & Baim & Mustacembelus armatus & Frozen semi-IQF \\
\hline 29. & Tara baim & Mustacembelus aculeatus & Frozen block \\
\hline 30. & Shol & Channa striatus & Frozen semi-IQF \\
\hline
\end{tabular}

\section{Quality of landed and processed fish in Kulierchar}

Fish and prawn at harvest were excellent as all having a DP (Defect Point) of around 1 (Table 7). But soon after that DP increased showing the maximum value in transporter's iced basket. DP of fish and prawn at the factory was good because of immediate icing was done soon after landing or promptly transported to the factory since the distance was very short. 
Table 4. Washing and cleaning of fish landed in Kulierchar

\begin{tabular}{|c|c|c|c|c|c|}
\hline \multirow[t]{3}{*}{ Fish } & \multicolumn{5}{|c|}{ Frequency of washing/cleaning ( $\%$ of unit practice) } \\
\hline & \multicolumn{2}{|c|}{ After harvest } & \multirow{2}{*}{$\begin{array}{l}\text { On way to } \\
\text { landing }\end{array}$} & \multirow{2}{*}{$\begin{array}{l}\text { Immediately } \\
\text { after landing }\end{array}$} & \multirow{2}{*}{$\begin{array}{c}\text { After wholesale } \\
\text { in Arat }\end{array}$} \\
\hline & River & Beel/pond & & & \\
\hline Golda & 65 & - & 25 & 7 & 100 \\
\hline Pabda & 37 & 26 & 10 & 5 & 100 \\
\hline Gulsha & 40 & 27 & 10 & 6 & 98 \\
\hline Baim & 20 & 18 & 15 & 2 & 100 \\
\hline Major carp & 26 & 15 & 5 & 0 & 96 \\
\hline Sarpunti & 10 & 17 & 8 & 5 & 98 \\
\hline Punti & 10 & 5 & 11 & 6 & 97 \\
\hline Boal & 27 & 19 & 5 & 2 & 85 \\
\hline Bele & 34 & 20 & 6 & 8 & 95 \\
\hline
\end{tabular}

Table 5. Container used to keep/transport fish landed in Kulierchar

\begin{tabular}{l|c|c|c|c}
\hline \multicolumn{1}{c}{ Fish } & $\begin{array}{c}\text { On board } \\
\text { vessel/during } \\
\text { harvest }\end{array}$ & $\begin{array}{c}\text { On way to } \\
\text { landing }\end{array}$ & During sale at Arat & During transportation \\
\hline Golda & $\begin{array}{c}\text { SBB, } \\
\text { Aluminium } \\
\text { container }\end{array}$ & $\begin{array}{c}\text { Polythene inner } \\
\text { wrapped SBB }\end{array}$ & Plastic mat on earth & $\begin{array}{l}\text { Plastic crate, Polythene inner } \\
\text { wrapped SBB }\end{array}$ \\
Pabda & SBB & SBB & Plastic mat on earth & Polythene inner wrapped SBB \\
Gulsha & SBB & SBB & Plastic mat on earth & Polythene inner wrapped SBB \\
Baim & SBB & SBB & Plastic mat on earth & Polythene inner wrapped SBB \\
Major carp & SBB & SBB & Plastic mat on earth & Polythene inner wrapped SBB \\
Sarpunti & SBB & SBB & Plastic mat on earth & Polythene inner wrapped SBB \\
Punti & SBB & SBB & Plastic mat on earth & Polythene inner wrapped SBB \\
Boal & SBB & SBB & Plastic mat on earth & Polythene inner wrapped SBB \\
Bele & SBB & SBB & Plastic mat on earth & Polythene inner wrapped SBB \\
\hline
\end{tabular}

$\mathrm{SBB}=$ Split bamboo basket

The processing plant in Kulierchar processed and exported more than 30 different types of conventional and value-added fish and shrimp products. Proximate compositions of most of the products were in good range showing no major deterioration of primary chemical conditions occurred. Peroxide values of prawn products were significantly lower, while those for fin-fishes were although little higher but still within the acceptable limit. 
Table 6. Icing of fish landed in Kulierchar

\begin{tabular}{l|c|c|c|c}
\hline \multirow{2}{*}{ Fish } & \multicolumn{4}{c}{ \% Practice of Icing } \\
\cline { 2 - 5 } & After harvest & On way to landing & Immediately after landing & $\begin{array}{c}\text { After wholesale in } \\
\text { Arat }\end{array}$ \\
\hline Golda & 7 & 32 & 23 & 100 \\
Pabda & 15 & 18 & 13 & 100 \\
Gulsha & 5 & 7 & 14 & 98 \\
Baim & 2 & 2 & 7 & 88 \\
Major carp & 2 & 5 & 8 & 97 \\
Sarpunti & 5 & 3 & 9 & 95 \\
Punti & 5 & 2 & 4 & 89 \\
Boal & 3 & 5 & 5 & 88 \\
Bele & 4 & - & 14 & 94 \\
\hline
\end{tabular}

Table 7. Freshness quality of landed fish in Kulierchar during the start of awareness development intervention

\begin{tabular}{|c|c|c|c|c|c|c|c|c|c|c|}
\hline \multirow[t]{2}{*}{ Fish } & \multicolumn{2}{|c|}{$\begin{array}{c}\text { Quality at } \\
\text { harvest }\end{array}$} & \multicolumn{2}{|c|}{$\begin{array}{l}\text { Quality at } \\
\text { landing }\end{array}$} & \multicolumn{2}{|c|}{$\begin{array}{l}\text { Quality at } \\
\text { aratders }\end{array}$} & \multicolumn{2}{|c|}{$\begin{array}{l}\text { Quality at } \\
\text { transporters }\end{array}$} & \multicolumn{2}{|c|}{$\begin{array}{c}\text { Quality at } \\
\text { factory } \\
\text { window }\end{array}$} \\
\hline & $\mathrm{DP}$ & Condn. & $\mathrm{DP}$ & Condn. & $\mathrm{DP}$ & Condn. & $\mathrm{DP}$ & Condn. & $\mathrm{DP}$ & Condn. \\
\hline $\begin{array}{l}\text { Macrobrachium } \\
\text { rosenbergii }\end{array}$ & 1.0 & Excellent & 2.0 & Good & 2.2 & Good & 2.6 & Good & 2.3 & Good \\
\hline Ompok Bimaculatus & 1.1 & Excellent & 2.1 & Good & 2.3 & Good & 2.8 & Good & 2.2 & Good \\
\hline Alia coila & 1.1 & Excellent & 2.1 & Good & 2.5 & Good & 2.9 & Good & 2.3 & Good \\
\hline Mystus vittatus & 1.6 & Excellent & 2.0 & Good & 2.6 & Good & 2.9 & Good & 2.0 & Good \\
\hline Mystua aor & 0.9 & Excellent & 2.2 & Good & 2.7 & Good & 3.1 & Good & 2.5 & Good \\
\hline Glossogobius giuris & 1.0 & Excellent & 2.5 & Good & 2.9 & Good & 3.0 & Poor & 2.5 & Good \\
\hline $\begin{array}{l}\text { Eutropiichthys } \\
\text { vacha }\end{array}$ & 1.0 & Excellent & 2.7 & Good & 2.9 & Good & 3.0 & Poor & 2.5 & Good \\
\hline
\end{tabular}

DP = Defect point; Condn. $=$ Condition

TVB nitrogen values were very low in shrimp products. In fish products, the values were comparatively higher (Table 8). But all such values were still lower than those to be considered spoilt. For a good quality fish, less than $35-40 \mathrm{mg}$ of TVBN/100g of fish is recommended (Gopakumar, 2002).

\section{Awareness creation and transfer of technology among the stakeholders}

The stakeholders existing awareness level was assessed and then several awareness development interventions were brought to them. Awareness in terms of benefit of good practices known to them was justifiably high in factory technicians. Other stakeholders 
had very shallow or poor knowledge on use of improved handling and processing of fish to keep the quality standard high (Table 9). Benefit of washing of fish after harvest was known to only $28 \%$ of fishermen and $37 \%$ fish mongers. The knowledge was of course higher among wholesalers and transporters (around 50\%). Benefit of adequate icing in maintaining the quality was known to only 35\% fishermen, 32\% fish monger and $40 \%$ fisher-women. Use of appropriate ice box for transporting fish was made mandatory by the government regulation but it was known to only $41 \%$ fishermen and fisher-women. Wholesalers and transporters were more aware to use good practices of fish handling and processing.

Table 8. Biochemical qualities of fish and shrimp products taken from the processing

\begin{tabular}{|c|c|c|c|c|c|c|}
\hline \multirow[t]{2}{*}{ Product } & \multicolumn{4}{|c|}{ Proximate composition } & \multirow{2}{*}{$\begin{array}{l}\text { Peroxide } \\
\text { value }\end{array}$} & \multirow{2}{*}{$\begin{array}{c}\text { TVBN } \\
(\mathrm{mg} / 100 \mathrm{~g})\end{array}$} \\
\hline & Moisture & Protein & Lipid & Ash & & \\
\hline Golda IQF & 77.67 & 20.60 & 0.95 & 0.38 & 2.1 & 18.16 \\
\hline Golda P\&D & 77.05 & 21.00 & 0.96 & 0.55 & 3.5 & 16.04 \\
\hline Golda PUD & 78.10 & 19.89 & 1.25 & 0.49 & 2.3 & 20.74 \\
\hline Chital S-IQF & 81.05 & 20.81 & 2.20 & 1.37 & 8.2 & 28.67 \\
\hline Aair S-IQF & 80.27 & 19.85 & 1.34 & 1.67 & 7.5 & 26.17 \\
\hline Gulsha & 81.00 & 20.02 & 1.90 & 1.11 & 10.4 & 33.49 \\
\hline Koi S-IQF & 80.40 & 19.66 & 1.86 & 1.23 & 7.8 & $27.03 \mathrm{~S}$ \\
\hline Pabda Block & 79.90 & 19.78 & 1.75 & 1.08 & 8.4 & 25.27 \\
\hline
\end{tabular}

$\mathrm{IQF}=$ Individual quick frozen; $\mathrm{P} \& \mathrm{D}=$ Peeled and deveined; S-IQF $=$ Semi-IQF; TVBN = Total volatile base nitrogen

Table 9. Awareness levels of stakeholders on good practice at the start of intervention

\begin{tabular}{l|c|c|c|c|c}
\hline \multicolumn{1}{c|}{ Stakeholders } & \multicolumn{5}{c}{ Benefit known to \% people } \\
\cline { 2 - 6 } & $\begin{array}{c}\text { Washing after } \\
\text { catch }\end{array}$ & $\begin{array}{c}\text { Icing after } \\
\text { catch }\end{array}$ & $\begin{array}{c}\text { Use of clean } \\
\text { container }\end{array}$ & Use of ice-box & $\begin{array}{c}\text { Keeping fish } \\
\text { in cool place }\end{array}$ \\
\hline Fishermen & 28 & 35 & 34 & 41 & 39 \\
Fish mongers & 37 & 32 & 42 & 64 & 39 \\
Wholesalers/ Aratders & 55 & 48 & 66 & 70 & 57 \\
Fish transporters & 51 & 62 & 79 & 76 & 67 \\
Fisher-women & 36 & 40 & 38 & 41 & 40 \\
Factory technicians & 89 & 92 & 96 & 98 & 86 \\
\hline
\end{tabular}

Various interventions were made to improve the existing awareness level of different stakeholders. They were brought under PRA and RRA, personal contacts, brain storming sessions and awareness development training programmes (Table 10). Training programmes were completely participatory and method or result demonstrations were 
mainly done to make such novice people understand the new things fully. Such participatory interventions, although lengthy and time consuming, improved awareness level on fish handling and quality improvement and made the transfer of technologies easier, smoother and timely.

Table 10. Skill development training of the stakeholders

\begin{tabular}{|c|c|c|c|c|}
\hline Types of training & Modus operande & $\begin{array}{c}\text { No of } \\
\text { training }\end{array}$ & Types of beneficiary & $\begin{array}{c}\text { No of } \\
\text { beneficiary } \\
\text { trained }\end{array}$ \\
\hline $\begin{array}{l}\text { Awareness } \\
\text { creation }\end{array}$ & PRA/RRA & 9 & $\begin{array}{l}\text { Fishermen/women/fish monger/ } \\
\text { fish traders }\end{array}$ & 265 \\
\hline $\begin{array}{l}\text { Improved fish } \\
\text { handling }\end{array}$ & Participatory MD & 3 & $\begin{array}{l}\text { Fishermen/women/fish } \\
\text { monger/transporters/aratders }\end{array}$ & 92 \\
\hline $\begin{array}{l}\text { Appropriate icing } \\
\text { of fish }\end{array}$ & Participatory MD & 2 & $\begin{array}{l}\text { Fishermen/women/fish } \\
\text { monger/transporters/aratders }\end{array}$ & 90 \\
\hline $\begin{array}{l}\text { Improved fish } \\
\text { processing }\end{array}$ & Participatory MD & 1 & Fisher-women/fishermen & 22 \\
\hline $\begin{array}{l}\text { Preparation of } \\
\text { low-cost ice-box } \\
\text { and drying tunnel }\end{array}$ & MD \& RD & 2 & $\begin{array}{l}\text { Fishermen/transporters/ } \\
\text { wholesalers }\end{array}$ & 32 \\
\hline $\begin{array}{l}\text { Fish quality } \\
\text { improvement/ } \\
\text { HACCP }\end{array}$ & $\begin{array}{l}\text { PRA / Group } \\
\text { Exercise }\end{array}$ & 1 & $\begin{array}{l}\text { Processing Technologist/ } \\
\text { Microbiologists/Factory operators }\end{array}$ & 14 \\
\hline
\end{tabular}

PRA = Participatory rapid appraisal; RRA = Rapid rural appraisal; MD = Method demonstration; $\mathrm{RD}=$ Result demonstration

\section{Improvement of awareness level on fish quality at the close of intervention}

Follow-up monitoring and assessment survey was conducted to observe the improvement of knowledge on improved fish handling and processing practices among the stakeholders. A tremendous increment of awareness level in all 5 sectors was noticed. Previous knowledge of fishermen on five sectors washing fish, icing, using clean container, using ice box and keeping fish in cool place were 28, 35, 34, 41 and $39 \%$ respectively in the above order (Table 9), which was increased to $68,76,80,85$ and $80 \%$ respectively in the same order (Table 11). All other stakeholders except processing factory operators and technician had significantly improved their awareness and skills. Processing factory personnel either studied the fish-processing course or had more than one training on such subjects before. The range of percent improvement was significantly higher in fishermen, fisher-women and fish monger (mostly above 100\%) but comparatively lower in wholesalers and transporters (14 - 71\%) (Table 11).

Freshness quality of the landed wet fish was reassessed (Table 12) at the close of intervention after 16 month to see the practical implication of such awareness improvement programmes. Comparatively better quality of fish was noticed in all five stages when compared to the quality of fish assessed during the start of intervention. 
Table 11. Awareness level of stakeholders on good practice at the close of intervention

\begin{tabular}{|c|c|c|c|c|c|c|c|c|c|c|}
\hline \multirow[t]{2}{*}{ Stakeholder } & \multicolumn{10}{|c|}{ Benefit known to $\%$ people } \\
\hline & $\begin{array}{c}\text { Washing } \\
\text { after } \\
\text { catch }\end{array}$ & $\%$ Dev & $\begin{array}{l}\text { Icing } \\
\text { after } \\
\text { catch }\end{array}$ & $\begin{array}{c}\% \\
\text { Dev }\end{array}$ & $\begin{array}{c}\text { Use of } \\
\text { clean } \\
\text { container }\end{array}$ & $\begin{array}{c}\% \\
\text { Dev }\end{array}$ & $\begin{array}{l}\text { Use of } \\
\text { ice-box }\end{array}$ & $\begin{array}{c}\% \\
\text { Dev }\end{array}$ & $\begin{array}{c}\text { Keeping } \\
\text { fish in cool } \\
\text { place }\end{array}$ & $\%$ Dev \\
\hline Fishermen & 68 & 142 & 76 & 117 & 80 & 135 & 85 & 107 & 80 & 105 \\
\hline Fish mongers & 63 & 72 & 68 & 113 & 85 & 103 & 85 & 33 & 83 & 128 \\
\hline Wholesaler/Aratders & 83 & 51 & 82 & 71 & 89 & 35 & 84 & 20 & 86 & 51 \\
\hline Fish transporters & 85 & 67 & 86 & 39 & 90 & 14 & 95 & 25 & 95 & 42 \\
\hline Fisher-women & 80 & 123 & 88 & 120 & 89 & 134 & 91 & 122 & 92 & 130 \\
\hline Factory technicians & 97 & 9 & 98 & 7 & 97 & 1 & 100 & 2 & 100 & 16 \\
\hline
\end{tabular}

Table 12. Freshness quality of landed fish in Kulierchar at the close of intervention

\begin{tabular}{|c|c|c|c|c|c|c|c|c|c|c|}
\hline \multirow[t]{2}{*}{ Fish } & \multicolumn{2}{|c|}{$\begin{array}{l}\text { Quality at } \\
\text { harvest }\end{array}$} & \multicolumn{2}{|c|}{$\begin{array}{l}\text { Quality at } \\
\text { landing }\end{array}$} & \multicolumn{2}{|c|}{$\begin{array}{l}\text { Quality at } \\
\text { Aratders }\end{array}$} & \multicolumn{2}{|c|}{$\begin{array}{l}\text { Quality at } \\
\text { transporters }\end{array}$} & \multicolumn{2}{|c|}{$\begin{array}{c}\text { Quality at } \\
\text { factory window }\end{array}$} \\
\hline & $\mathrm{DP}$ & Condn. & $\mathrm{DP}$ & Condn. & $\mathrm{DP}$ & Condn. & $\mathrm{DP}$ & Condn. & $\mathrm{DP}$ & Condn. \\
\hline $\begin{array}{l}\text { Macrobrachium } \\
\text { rosenbergii }\end{array}$ & 1.0 & Excellent & 1.9 & Excel & 2.1 & Good & 2.2 & Good & 2.0 & Good \\
\hline Ompok Bimaculatus & 1.0 & Excellent & 2.0 & Good & 2.1 & Good & 2.3 & Good & 2.1 & Good \\
\hline Alia coila & 1.1 & Excellent & 2.0 & Good & 2.2 & Good & 2.5 & Good & 2.0 & Good \\
\hline Mystus vittatus & 1.1 & Excellent & 1.9 & Excel & 2.5 & Good & 2.5 & Good & 1.9 & Excel \\
\hline Mystua aor & 1.0 & Excellent & 2.0 & Good & 2.5 & Good & 2.8 & Good & 2.1 & Good \\
\hline Glossogobius giuris & 1.0 & Excellent & 2.3 & Good & 2.5 & Good & 2.7 & Good & 2.3 & Good \\
\hline Eutropiichthys vacha & 1.0 & Excellent & 2.4 & Good & 2.5 & Good & 2.7 & Good & 2.4 & Good \\
\hline
\end{tabular}

$\mathrm{DP}=$ Defect point; Condn $=$ Condition

\section{CONCLUSION}

Participatory tools employed in this study was found to be effective in developing awareness of stakeholders in different value chains of wet fish handling and distribution and reducing post-harvest loss in Kulierchar. Study suggested that any technology to be used by the rural poor should be developed and improved with full participation of the ultimate users. Considering the dwindling situation in the post harvest sector of exportable fish and prawn throughout the country, such participatory stakeholder based technique can be employed where involvement of all beneficiaries will ensure sustainable transfer of improved technology. 


\section{REFERENCES}

AOAC, 1990. Official Methods of Analysis. 15th ed. Association of Official Analytical Chemists, Washington DC.

Gopakumar, K. 2002. Post-mortem Changes in Fish and Quality Assessment. In: Textbook of Fish Processing Technology. K. Gopakumar (ed). Indian Council of Agricultural Research, New Delhi. 491p.

Howgate, P. A., Johnston, K. and Whittle, J. 1992. Multilingual Guide to EC Freshness Grades for Fishery Products. Torry Research Station. Food Safety Directorate, Ministry of Agriculture, Fisheries and Food, Aberdeen, Scotland.

Miwa, K. and Ji, L. S. 1992. Laboratory Manual on Analytical Methods and Procedures for Fish and Fish Products. $2^{\text {nd }}$ edn. Marine Fisheries Research Department, SEAFDEC/JICA.

Nowsad, A. K. M. A. 2004. Landing Center Monitoring. Report on a survey research done in collaboration with Bangladesh Center for Advanced Studies and Center for Natural resources Studies. ECFC Field Rep. 2004. 189 pp.

Nowsad, A. K. M. A. 2005a. Low Cost Processing of Fish in Coastal Bangladesh. ECFC Field Doc. Food and Agriculture Organization of the United Nations, Dhaka. 88 pp.

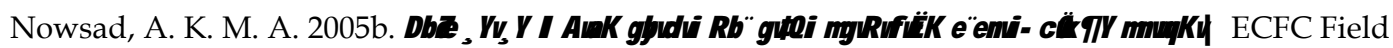
Doc. Food and Agriculture Organization of the United Nations, Dhaka. 73 pp.

Sakaguchi, M. 1990. Objective and subjective methods for measuring freshness of fish. Department of Fisheries, Faculty of Agriculture, Kyoto University, Sakyo-ku 606, Kyoto, Japan.

Shil, R. N. and Debnath, S. C. 1992. An Introduction to the Theory of Statistics. 2nd edn., Publisher Minati Shil and Anita Debnath, Mymensingh, 240-320 pp. 